\title{
Impact of Moisture Management and Zinc Fertilization on Performance of Pearlmillet (Pennisetum glaucum L.) Under Rainfed Conditions
}

\author{
G.L. Choudhary ${ }^{1}$, K.S. Rana ${ }^{2}$, R.S. Bana ${ }^{2}$ and K. Prajapat ${ }^{3}$ \\ ${ }^{1}$ Regional Research Sub-Station, Jalalgarh, Purnea, Bihar-854 327, India \\ ${ }^{2}$ Division of Agronomy, ICAR-Indian Agricultural Research Institute, New Delhi-110 012, India \\ ${ }^{3}$ ICAR-Central Soil Salinity Research Institute, Karnal, Haryana-132 001, India \\ *Corresponding author
}

\section{A B S T R A C T}

The present study was conducted during kharif, 2012 and 2013 at ICAR-Indian Agricultural Research Institute, New Delhi to find out the effect of moisture management and zinc fertilization on performance of pearlmillet under rainfed conditions. Results of

\section{Keywords}

Flat bed, Crop residue, Narrow bed and furrow, Moisture management, Root length, Root volume, Grain yield, Pearlmillet, Zinc.

Article Info

Accepted: 12 March 2017 Available Online: 10 April 2017 two year study showed considerable improvement in growth and productivity of pearlmillet. Flat bed with 5.0 t/ha crop residue recorded significantly higher plant height, dry matter accumulation, number of earheads, grain weight per earhead, yield and profitability as compared to flat bed without crop residue and flat bed with $2.5 \mathrm{t} / \mathrm{ha}$ crop residue. In terms of total number of tillers, length of earhead, 1,000 grain weight and returns per rupee invested flat bed with 2.5 and 5.0 t/ha crop residue and narrow bed and furrow with $2.5 \mathrm{t}$ /ha crop residue remained statistically similar with each other. However, significantly higher values of root parameters viz., root length, root volume and root dry weight were observed with flat bed without crop residue. Under zinc fertilization treatments application of 5.0 and $2.5 \mathrm{~kg} \mathrm{Zn} / \mathrm{ha}$ being at par with each other and proved significantly better over control in terms of growth parameters except dry matter, yield attributes, stover yield, harvest index and returns per rupee invested of pearlmillet. Whereas, fertilization of pearlmillet with $5.0 \mathrm{~kg} \mathrm{Zn} / \mathrm{ha}$ resulted significantly higher dry matter accumulation, grain and biological yield and profitability over lower levels of zinc. Residual effect of zinc fertilization was also found to be significant in pearlmillet. Most of the parameters of pearlmillet showed significant response only up to $2.5 \mathrm{~kg} \mathrm{Zn} / \mathrm{ha}$. Final results revealed that pearlmillet shown under flat bed with 5.0 t/ha crop residue or narrow bed and furrow with $2.5 \mathrm{t} / \mathrm{ha}$ crop residue and application of $2.5 \mathrm{~kg} \mathrm{Zn} / \mathrm{ha}$ to pearlmillet or chickpea were proved to be better.

\section{Introduction}

Among cereal crops pearlmillet (Pennisetum glaucumL.) is the fifth most important grain crop next to rice, wheat, maize and sorghum. The crop is cultivated for grain as well as fodder in the semi-arid tropical regions of Africa and Asia including India. In India, annual planting area is 7.12 million hectares $p$ roducing nearly 9.05 million tonnes of grains (GOI, 2015). Today, it is getting more attention due to increasing evidence of less seasonal rainfall, terminal heat, frequent occurrence of extreme weather events coupled with scanty water resources (Singh et al., 2010). Pearlmillet traditionally is an 
indispensable component of dry-farming system and it is considering more efficient in utilization of soil moisture, and has a higher level of heat tolerance than even sorghum and maize. It is the food for millions of people in the poor soils of semi-arid tropics. It occupies a distinct position in the agricultural economy of the country. With the advent of pearlmillet hybrids in mid-sixties, the pearlmillet cultivation received a fillip. As a result, the productivity almost quadruple from around $350 \mathrm{~kg}$ in mid-sixties to around $1272 \mathrm{~kg}$ in 2012, the crop is mostly confined to low fertile water deficit soils. Because of its remarkable ability to withstand and grow in harsh environment, reasonable and nearly assured harvests are obtained. The main problem of rainfed areas is uncertainty and uneven distribution of rainfall and loss of water through runoff which leads to low and unstable productivity due to moisture stress at critical stages of crop growth. It is well known fact that about 85 per cent of annual rainfall is received during south-west monsoon season. In this period knowledge of crop growth phases and moisture availability is more essential because the deficiency of rain water at any critical growth stage may affect the plant growth and yield. Moisture stress further affect the nutrient availability to the crop since nutrient mobility depends on optimum soil moisture. The risk factor can be minimized through in-situ moisture conservation, adoption of suitable crops and their varieties (Munish Kumar et al., 2008).

Residue application helps in maintaining proper growth and development of crop by conserving the moisture in soil profile and ultimately enhanced the productivity of crops (Singh et al., 2012 and Tetarwal et al., 2012). Moisture conservation through organic residue application is a viable approach to retain soil moisture and nutrient under water scarcity situations (Sharma et al., 2010). Another problem of present scenario is zinc deficiency in soils. It is well known fact that zinc is now considered as fourth most important yield-limiting nutrient after, nitrogen, phosphorus and potassium (Maclean et al., 2002). Increasing zinc concentration in food crops, resulting better crop production and improved human health is an important global challenge. Among the micronutrients $\mathrm{Zn}$ deficiency is occurring in both crops and human (White and Zasoski, 1999). Zn deficiency reduces not only the grain yield, but also the nutritional quality of grain and ultimately nutritional quality of human diet. $\mathrm{Zn}$ is essential for both plants and animals because it is a structural constituent and regulatory co-factor in enzymes and proteins involved in many biochemical pathways. Besides improving photosynthesis and regulation of auxin concentration, $\mathrm{Zn}$ plays an important role in nitrogen metabolism and protein synthesis. Under dryland conditions reduced soil moisture in surface soil layer reduce zinc adsorption and may cause zinc deficiency. Cereal crops are generally the most susceptible to zinc deficiency and show a high response to zinc fertilization. Agronomic approaches such as application of $\mathrm{Zn}$-containing fertilizers appear to be a rapid and simple solution to address the $\mathrm{Zn}$ deficiency in crop and human health. Chaube et al., (2007) and Badiyala and Chopra (2011) were reported that use of $\mathrm{Zn}$ increase the productivity as well as improve the fertility status of soil. Thus, keeping these facts in view, a research problem was undertaken to find out the effect of zinc fertilization under different moisture management practices on performance of pearlmillet under rainfed conditions.

\section{Materials and Methods}

A field experiment was conducted at the research farm of ICAR-Indian Agricultural Research Institute, New Delhi during kharif 2012 and 2013 under rainfed conditions. The 
experimental farm is situated at $28^{\circ} 37^{\prime} \mathrm{N}$ latitude, $77^{\circ} 09^{\prime} \mathrm{E}$ longitude and $224 \mathrm{~m}$ above mean sea level. The experimental soil was sandy loam in texture having $61.48 \%$ sand, $12.66 \%$ silt and $25.86 \%$ clay contents. The experimental soil was low in available nitrogen (135.4 kg N/ha), medium in available phosphorus (12.8 $\mathrm{kg} \mathrm{P} / \mathrm{ha})$, potassium (178.8 $\mathrm{kg} \mathrm{K} / \mathrm{ha})$ and $\mathrm{Zn}(0.63$ $\mathrm{mg} / \mathrm{kg}$ of soil) and low in organic carbon content $(0.40 \%)$. The $\mathrm{pH}$ of the soil was 7.7 and determined in soil water suspension in the ratio of 1:2.5 with glass electrode $\mathrm{pH}$ meter. The experiment comprised of four treatments of moisture management (Flat Bed, Flat Bed with 2.5 t/ha crop residue, Flat Bed with 5.0 t/ha crop residue and Narrow Bed and Furrow with $2.5 \mathrm{t} / \mathrm{ha}$ crop residue) in main plot and three treatments of zinc fertilization (control, $2.5 \mathrm{~kg} \mathrm{Zn} / \mathrm{ha}$ and $5.0 \mathrm{~kg} \mathrm{Zn} / \mathrm{ha}$ ) in sub plot to pearlmillet and in sub-sub plot to chickpea. The experiment was laid out in split plot design during kharif 2012 and in split-split plot design from subsequent season and replicated thrice. The pearlmillet variety 'Pusa composite 443' was taken for experiment and planted at $50 \mathrm{~cm} \times 15 \mathrm{~cm}$ spacing. Recommended dose of fertilizers (60 $\mathrm{kg} \mathrm{N}, 40 \mathrm{~kg} \mathrm{P}_{2} \mathrm{O}_{5}$ and $40 \mathrm{~kg} \mathrm{~K}_{2} \mathrm{O} / \mathrm{ha}$ ) were applied to experimental crop. Half dose of nitrogen and full dose of phosphorus and potassium was applied as basal dose at the time of sowing and remaining half dose of nitrogen was as top dressing at 40 DAS. Chickpea residue was applied in pearlmillet crop as per treatment just after sowing as moisture management treatments during both the years. Zinc fertilization treatments were applied as per treatment through zinc sulphate $\left(\mathrm{ZnSO}_{4} .7 \mathrm{H}_{2} \mathrm{O}\right)$ containing $21 \%$ zinc and $10 \%$ $\mathrm{S}$ at the time of sowing as basal dose. The amount of sulphur was adjusted through SSP in all the plots. The crop was grown with recommended package of practices. Need based application of pesticide was also followed to protect the crops from termites.
The crop was taken 81 days and 77 days for completion of life cycle during 2012 and 2013, respectively.

Five plants were selected randomly from each plot, tagged permanently and used for measurement of plant height. For dry matter accumulation five plants from each plot were uprooted randomly from sample rows and after removal of root portion, the samples were first air dried for some days followed by dried in an electric oven at $65^{\circ} \mathrm{C}$ till constant weight. The weight was recorded and expressed as g/plant. The total number of tillers and number of earheads per metre row length were counted at harvest from three different spots from each plot and the average was worked out. Root samples were taken from the sample row at flowering stage 50 DAS. A root auger of $4.8 \mathrm{~cm}$ diameter and 10 $\mathrm{cm}$ height (core volume $=180.86 \mathrm{~cm} 3$ ) was used to take root samples up to $0-15 \mathrm{~cm}$ depth of soil profile. The root samples taken from each plot were thoroughly washed in running water to remove the dust particles. Then, root samples were put in to polythene bag and used to measure root length and volume by scanning. Scanning and image analysis using RHIZO system was operated in a computer mounted with the scanner of RHIZO system. After taking root length and volume, root samples were put first for air dried for some days followed by dried in an electric oven at $65^{\circ} \mathrm{C}$ till constant weight. The weight was recorded and expressed as g/plant. Five earheads were randomly selected from each plot and the length of earhead was measured from the basal whorl of spikelet to the tip of earhead. The length of earhead was measured in centimetre and mean length was calculated. Same five earheads of pearlmillet which were used to measure length were also used for recording grain weight. The weight of the thoroughly sun dried harvested produce from net area of each plot was recorded separately before threshing and expressed as biological 
yield in t/ha. After proper drying harvested produce were threshed separately. Grain yield from each net plot was recorded and computed as grain yield $t / h a$. The stover yield for each plot was worked out by subtracting grain yield from total biomass of each net plot and stover yield was expressed in t/ha. Economics of different treatment was worked out by taking into account the cost of inputs and income obtained from output based on the prevailing market price. Statistical analysis of the data was carried out using standard analysis of variance (Gomez and Gomez, 1984).

\section{Results and Discussion}

\section{Moisture management practices}

Growth parameters pearlmillet viz., plant height, dry matter accumulation and total number of tillers was significantly influenced by moisture management practices (Table 1). Flat bed with 5.0 t/ha crop residue recorded significantly higher plant height $(272.2 \mathrm{~cm})$ and dry matter accumulation ( $84.2 \mathrm{~g} / \mathrm{plant}$ ) as compared to flat bed without crop residue and flat bed with $2.5 \mathrm{t} / \mathrm{ha}$ crop residue but it was found statistically at par with narrow bed and furrow with $2.5 \mathrm{t} / \mathrm{ha}$ crop residue. However, in terms of total number of tillers per metre row length all the three moisture management practices which have crop residue remained at par with each other and proved significantly better over flat bed without crop residue. Under moisture stress conditions in search of moisture the flat bed planted pearlmillet recorded significantly higher value of rooting parameters (root length, root volume and root dry weight) as compared to crop residue applied treatments (Table 1). The improvement in growth parameters of pearlmillet planted under residue applied moisture management practices might be due to that residue cover helped to conserve soil moisture available through rainfall (Mulumba and Lal, 2008) and continuously provided to the needs of crops. Moreover, applied residue as moisture management practice also enhanced the nutrient supply through decomposition of organic residue coupled with favorable moisture condition created conducive environment for plant growth and development (Singh et al., 2012; Dass et al., 2013).

Moisture management practices were also had significant effect on yield attributes and yield of pearlmillet (Tables 2 and 3). Flat bed with $5.0 \mathrm{t} / \mathrm{ha}$ crop residue being at par to narrow bed and furrow with $2.5 \mathrm{t} / \mathrm{ha}$ crop residue and recorded significantly higher number of earheads per metre row length and grain weight per earhead over flat bed without crop residue and flat bed with $2.5 \mathrm{t} / \mathrm{ha}$ crop residue. However, flat bed with 5.0 t/ha crop residue found statistically similar with both the residue applied treatments and produced significantly longer earhead $(30.0 \mathrm{~cm})$ with higher 1,000 grain weight $(8.48 \mathrm{~g})$ than flat bed without crop residue. The favourable improvements in yield attributes was due to the favourable effect of moisture management practices on growth parameters, leading to greater nutrient uptake, efficient partitioning of metabolites and adequate accumulation and translocation of photosynthates. Adequate supply of moisture in general is known to enhance the growth and dry matter production of crops directly and indirectly by increasing the availability and utilization of nutrients (Tetarwal et al., 2012). Pearlmillet grown on flat bed with 5.0 t/ha crop residue produced significantly higher grain (2.62 t/ha), stover (8.43 t/ha) and biological yield (11.05 t/ha) than flat bed without crop residue and flat bed with $2.5 \mathrm{t} / \mathrm{ha}$ crop residue followed by narrow bed and furrow with 2.5 t/ha crop residue. Harvest index was increased linearly with moisture management practices but fails to bring any significant improvement. The increase in grain yield of pearlmillet with flat 
bed with 5.0 t/ha crop residue might be due to the better availability of moisture and addition of organic matter. Rapid decomposition of organic residue helped in greater availability of nutrients, which led to increase in growth and yield attributes and finally the grain yield. Similar findings were also reported by Kumar and Gautam (2004) and Parihar et al., (2012). Economics of pearlmillet was also influenced significantly by moisture management practices (Table 4). Flat bed with 5.0 t/ha crop residue remained at par to narrow bed and furrow with 2.5 t/ha crop residue, fetched significantly higher profitability of ₹ 27,993/ha which was higher by ₹ 8,415/ha and ₹ 3,663/ha over flat bed without crop residue and flat bed with 2.5 t/ha crop residue, respectively. In terms of returns per rupee invested pearlmillet sown on narrow bed and furrow with $2.5 \mathrm{t} / \mathrm{ha}$ crop residue recorded significantly higher returns per rupee invested (1.29) over flat bed without crop residue. Flat bed with $5.0 \mathrm{t} / \mathrm{ha}$ crop residue fetched highest net returns but the $\mathrm{B}: \mathrm{C}$ ratio was higher under narrow bed and furrow with 2.5 tha crop residue, because of higher cost of residue under this treatment. Similar findings were also reported in sorghum crop by Guled et al., (2011) and Thakur et al., (2011).

\section{Zinc fertilization to pearlmillet}

Zinc fertilization treatments had significant effect on growth parameters of pearlmillet namely plant height, dry matter accumulation, total number of tillers, root length, root volume and root dry weight (Table 1). Application of $5.0 \mathrm{~kg} \mathrm{Zn/ha} \mathrm{being} \mathrm{at} \mathrm{par} \mathrm{with}$ $2.5 \mathrm{~kg} \mathrm{Zn} / \mathrm{ha}$, produced significantly taller plants $(265.6 \mathrm{~cm})$ with higher total number of tillers (19.9 tillers per metre row length), root length $(373.8 \mathrm{~cm} /$ plant$)$, root volume $(10.68$ $\mathrm{cm}^{3} /$ plant $)$ and root dry weight (6.976 g/plant) over control. However, dry matter accumulation of pearlmillet was increased significantly with increasing levels of zinc fertilization up to $5.0 \mathrm{~kg} \mathrm{Zn} / \mathrm{ha}$. The favourable influence of applied zinc on different growth parameters of pearlmillet and chickpea ascribed to its involvement in various metabolic activities, controlling auxin levels and nucleic acids (Marschner, 1995). Zinc is also an essential component of enzymes responsible for assimilation of nitrogen which helps in chlorophyll formation and plays an important role in nitrogen metabolism contributing towards increase in growth and development of plant (Badiyala and Chopra, 2011).

Yield attributes, yield and harvest index of pearlmillet were enhanced significantly with zinc fertilization treatments (Table 2 and 3). Application of $5.0 \mathrm{~kg} \mathrm{Zn/ha}$ to pearlmillet remained at par with $2.5 \mathrm{~kg} \mathrm{Zn} / \mathrm{ha}$, produced significantly higher number of earheads per metre row length, length of earhead, grain weight per earhead and test weight as compared to control. As already discussed in preceding paragraph that zinc plays an important role in nitrogen metabolism and formation of chlorophyll and carbohydrate, which leads to maintain photosynthetic activity for longer period and finally results in increasing the yield attributes of the crop (Mehta et al., 2008). Fertilization of pearlmillet with $5.0 \mathrm{~kg} \mathrm{Zn} / \mathrm{ha}$ recorded significantly higher grain yield (2.54 t/ha) and biological yield (10.65 t/ha) than lower levels of zinc. Whereas, in terms of stover yield and harvest index direct application of 5.0 and 2.5 $\mathrm{kg} \mathrm{Zn/ha} \mathrm{being} \mathrm{at} \mathrm{par} \mathrm{with} \mathrm{other} \mathrm{and} \mathrm{proved}$ significantly better than unfertilized one. The cumulative beneficial effect of growth and yield attributing characters was finally reflected in grain yield of pearlmillet. These results are in close conformity with Mehta et al., (2008) and Ram Pratap et al., (2008). Profitability of pearlmillet was increased significantly with increasing levels of zinc up to $5.0 \mathrm{~kg} \mathrm{Zn/ha} \mathrm{(Table} \mathrm{4).} \mathrm{Zinc} \mathrm{fertilization}$ treatment received $5.0 \mathrm{~kg} \mathrm{Zn} / \mathrm{ha}$ proved 
significantly profitable one with returns of ₹ $27,463 /$ ha with returns of ₹ 1.27 per rupee invested. This might be due to the cost involved under this treatment was comparatively lower than its additional income, which led to more returns under this treatment. Similar findings were also reported by Jakhar et al., (2006).

\section{Residual effect of zinc fertilization}

The residual effect of preceding zinc fertilization treatments applied to chickpea was examined during second year of study and results were found to be significant on all the growth parameters of pearlmillet (Table
1). Growth parameters of pearlmillet namely plant height, dry matter accumulation, total number of tillers and rooting characteristics were increased significantly up to $2.5 \mathrm{~kg}$ $\mathrm{Zn} / \mathrm{ha}$. Yield attributes and yield of pearlmillet were also influenced significantly with residual effect of zinc fertilization (Tables 2 and 3). Wherein, application of 5.0 $\mathrm{kg} \mathrm{Zn/ha} \mathrm{was} \mathrm{remained} \mathrm{at} \mathrm{par} \mathrm{with} 2.5 \mathrm{~kg}$ $\mathrm{Zn} / \mathrm{ha}$ and produced significantly higher number of earheads per metre row length (13.9), length of earhead $(29.1 \mathrm{~cm})$, grain weight per earhead (18.2 g), stover yield (7.88 $\mathrm{t} / \mathrm{ha})$ and biological yield (10.30 t/ha) over control.

Table.1 Effect of moisture management and zinc fertilization on growth parameters of pearlmillet

\begin{tabular}{|c|c|c|c|c|c|c|}
\hline Treatment & $\begin{array}{l}\text { Plant } \\
\text { height } \\
(\mathrm{cm})\end{array}$ & $\begin{array}{c}\text { Dry } \\
\text { matter } \\
\text { (g/plant) }\end{array}$ & $\begin{array}{c}\text { Total } \\
\text { tillers } \\
\text { per } \\
\text { metre } \\
\text { row }\end{array}$ & $\begin{array}{l}\text { Root } \\
\text { length } \\
(\mathrm{cm} / \\
\text { plant })\end{array}$ & $\begin{array}{c}\text { Root } \\
\text { volume } \\
\left(\mathrm{cm}^{3} /\right. \\
\text { plant) }\end{array}$ & $\begin{array}{c}\text { Root } \\
\text { dry } \\
\text { weight } \\
\text { (g/ } \\
\text { plant) }\end{array}$ \\
\hline \multicolumn{7}{|l|}{ Moisture management } \\
\hline Flat Bed & 236.9 & 62.5 & 17.4 & 398.7 & 11.24 & 7.260 \\
\hline Flat Bed $+2.5 \mathrm{t} / \mathrm{ha}$ crop residue & 257.7 & 75.0 & 19.2 & 350.2 & 10.03 & 6.470 \\
\hline Flat Bed +5.0 t/ha crop residue & 272.2 & 84.2 & 20.1 & 328.0 & 9.36 & 6.136 \\
\hline$* \mathrm{NBF}+2.5 \mathrm{t} / \mathrm{ha}$ crop residue & 265.3 & 80.7 & 19.7 & 339.1 & 9.68 & 6.332 \\
\hline Sem \pm & 4.01 & 1.74 & 0.33 & 8.49 & 0.20 & 0.136 \\
\hline $\mathrm{CD}(\mathrm{P}=0.05)$ & 12.37 & 5.37 & 1.01 & 26.15 & 0.61 & 0.419 \\
\hline \multicolumn{7}{|l|}{ Zinc fertilization to pearlmillet } \\
\hline Control & 247.8 & 69.7 & 18.0 & 326.5 & 9.30 & 6.012 \\
\hline $2.5 \mathrm{~kg} \mathrm{Zn} / \mathrm{ha}$ & 260.6 & 76.9 & 19.4 & 361.7 & 10.25 & 6.660 \\
\hline $5.0 \mathrm{~kg} \mathrm{Zn} / \mathrm{ha}$ & 265.6 & 80.2 & 19.9 & 373.8 & 10.68 & 6.976 \\
\hline SEm \pm & 2.39 & 1.13 & 0.22 & 5.95 & 0.15 & 0.112 \\
\hline $\mathrm{CD}(\mathrm{P}=0.05)$ & 6.90 & 3.25 & 0.64 & 17.14 & 0.44 & 0.324 \\
\hline \multicolumn{7}{|l|}{ Zinc fertilization to chickpea } \\
\hline Control & 255.6 & 74.0 & 18.8 & 346.5 & 9.88 & 6.420 \\
\hline $2.5 \mathrm{~kg} \mathrm{Zn/ha}$ & 258.6 & 75.9 & 19.1 & 355.9 & 10.12 & 6.577 \\
\hline $5.0 \mathrm{~kg} \mathrm{Zn/ha}$ & 259.9 & 76.9 & 19.3 & 359.6 & 10.23 & 6.650 \\
\hline SEm \pm & 0.95 & 0.43 & 0.10 & 3.00 & 0.06 & 0.040 \\
\hline $\mathrm{CD}(\mathrm{P}=0.05)$ & 2.66 & 1.22 & 0.29 & 8.42 & 0.17 & 0.111 \\
\hline
\end{tabular}

*Narrow Bed and Furrow 
Table.2 Effect of moisture management and zinc fertilization on yield attributes of pearlmillet

\begin{tabular}{lcccc}
\hline Treatment & $\begin{array}{c}\text { Number of } \\
\text { earheads per } \\
\text { meter row }\end{array}$ & $\begin{array}{c}\text { Length of } \\
\text { earhead } \\
(\mathrm{cm})\end{array}$ & $\begin{array}{c}\text { Grain weight } \\
\text { per earhead } \\
(\mathrm{g})\end{array}$ & $\begin{array}{c}\text { 1,000-grain } \\
\text { weight }(\mathrm{g})\end{array}$ \\
\hline Moisture management & & & & \\
Flat Bed & 11.9 & 26.2 & 15.6 & 7.81 \\
Flat Bed + 2.5 t/ha crop residue & 13.8 & 28.9 & 17.8 & 8.25 \\
Flat Bed + 5.0 t/ha crop residue & 14.8 & 30.0 & 19.6 & 8.48 \\
*NBF + 2.5 t/ha crop residue & 14.5 & 29.6 & 18.9 & 8.34 \\
Sem \pm & 0.28 & 0.42 & 0.33 & 0.113 \\
$\mathrm{CD}(\mathrm{P}=0.05)$ & 0.87 & 1.30 & 1.03 & 0.349 \\
Zinc fertilization to pearlmillet & & & & \\
Control & 13.0 & 27.3 & 16.9 & 8.02 \\
$2.5 \mathrm{~kg}$ Zn/ha & 14.0 & 28.9 & 18.2 & 8.25 \\
$5.0 \mathrm{~kg}$ Zn/ha & 14.3 & 29.7 & 18.8 & 8.39 \\
SEm \pm & 0.14 & 0.28 & 0.23 & 0.075 \\
CD $(\mathrm{P}=0.05)$ & 0.40 & 0.82 & 0.67 & 0.216 \\
Zinc fertilization to chickpea & & & & \\
Control & 13.6 & 28.1 & 17.7 & 8.16 \\
2.5 kg Zn/ha & 13.8 & 28.8 & 18.0 & 8.23 \\
$5.0 \mathrm{~kg}$ Zn/ha & 13.9 & 29.1 & 18.2 & 8.27 \\
SEm \pm & 0.06 & 0.16 & 0.10 & 0.034 \\
$\mathrm{CD}(\mathrm{P}=0.05)$ & 0.17 & 0.45 & 0.29 & $\mathrm{NS}$ \\
\hline
\end{tabular}

*Narrow Bed and Furrow

Table.3 Effect of moisture management and zinc fertilization on yield and harvest index of pearlmillet

\begin{tabular}{|c|c|c|c|c|}
\hline Treatment & $\begin{array}{c}\text { Grain yield } \\
(\mathrm{t} / \mathrm{ha})\end{array}$ & $\begin{array}{c}\text { Stover yield } \\
(\mathrm{t} / \mathrm{ha})\end{array}$ & $\begin{array}{c}\text { Biological } \\
\text { yield (t/ha) }\end{array}$ & $\begin{array}{c}\text { Harvest index } \\
(\%)\end{array}$ \\
\hline \multicolumn{5}{|l|}{ Moisture management } \\
\hline Flat Bed & 1.96 & 6.64 & 8.60 & 22.76 \\
\hline Flat Bed $+2.5 \mathrm{t} / \mathrm{ha}$ crop residue & 2.34 & 7.64 & 9.97 & 23.44 \\
\hline Flat Bed +5.0 t/ha crop residue & 2.62 & 8.43 & 11.05 & 23.71 \\
\hline$* \mathrm{NBF}+2.5 \mathrm{t} / \mathrm{ha}$ crop residue & 2.55 & 8.26 & 10.81 & 23.53 \\
\hline $\operatorname{Sem} \pm$ & 0.04 & 0.14 & 0.17 & 0.30 \\
\hline $\mathrm{CD}(\mathrm{P}=0.05)$ & 0.12 & 0.43 & 0.52 & NS \\
\hline \multicolumn{5}{|l|}{ Zinc fertilization to pearlmillet } \\
\hline Control & 2.14 & 7.24 & 9.37 & 22.83 \\
\hline $2.5 \mathrm{~kg} \mathrm{Zn} / \mathrm{ha}$ & 2.42 & 7.88 & 10.30 & 23.46 \\
\hline $5.0 \mathrm{~kg} \mathrm{Zn} / \mathrm{ha}$ & 2.54 & 8.11 & 10.65 & 23.80 \\
\hline $\mathrm{SEm} \pm$ & 0.03 & 0.09 & 0.11 & 0.26 \\
\hline $\mathrm{CD}(\mathrm{P}=0.05)$ & 0.08 & 0.27 & 0.31 & 0.75 \\
\hline \multicolumn{5}{|l|}{ Zinc fertilization to chickpea } \\
\hline Control & 2.29 & 7.57 & 9.86 & 23.22 \\
\hline $2.5 \mathrm{~kg} \mathrm{Zn/ha}$ & 2.38 & 7.78 & 10.16 & 23.39 \\
\hline $5.0 \mathrm{~kg} \mathrm{Zn} / \mathrm{ha}$ & 2.42 & 7.88 & 10.30 & 23.47 \\
\hline $\mathrm{SEm} \pm$ & 0.02 & 0.04 & 0.05 & 0.09 \\
\hline $\mathrm{CD}(\mathrm{P}=0.05)$ & 0.04 & 0.12 & 0.15 & NS \\
\hline
\end{tabular}

*Narrow Bed and Furrow 
Table.4 Effect of moisture management and zinc fertilization on economics of pearlmillet

\begin{tabular}{lccc}
\hline Treatment & $\begin{array}{c}\text { Cost of cultivation } \\
(₹ / \text { Pa) }\end{array}$ & Profitability (₹/ha) & $\begin{array}{c}\text { Returns per rupee } \\
\text { invested }\end{array}$ \\
\hline Moisture management & & & \\
Flat Bed & 18,918 & 19,578 & 1.03 \\
Flat Bed + 2.5 t/ha crop residue & 20,968 & 24,430 & 1.16 \\
Flat Bed + 5.0 t/ha crop residue & 22,618 & 27,993 & 1.24 \\
*NBF + 2.5 t/ha crop residue & 21,568 & 27,801 & 1.29 \\
Sem \pm & - & 717 & 0.03 \\
$\mathrm{CD}(\mathrm{P}=0.05)$ & - & 2,211 & 0.11 \\
Zinc fertilization to pearlmillet & 20,509 & 21,500 & \\
Control & 21,084 & 25,888 & 1.04 \\
$2.5 \mathrm{~kg} \mathrm{Zn/ha}$ & 21,459 & 27,463 & 1.22 \\
$5.0 \mathrm{~kg}$ Zn/ha & - & 478 & 1.27 \\
$\mathrm{SEm} \pm$ & - & 1,377 & 0.02 \\
$\mathrm{CD}(\mathrm{P}=0.05)$ & & & 0.07 \\
Zinc fertilization to chickpea & 21,018 & 23,652 & \\
Control & 21,018 & 25,231 & 1.12 \\
$2.5 \mathrm{~kg} \mathrm{Zn/ha}$ & 21,018 & 25,968 & 1.19 \\
$5.0 \mathrm{~kg} \mathrm{Zn/ha}$ & - & 260 & 1.23 \\
$\mathrm{SEm} \pm$ & - & 731 & 0.01 \\
$\mathrm{CD}(\mathrm{P}=0.05)$ & & & 0.03 \\
\hline
\end{tabular}

*Narrow Bed and Furrow

Whereas, the residual effect of zinc on grain yield of pearlmillet was found significant up to the higher level of zinc fertilization, wherein, application of $5.0 \mathrm{~kg} \mathrm{Zn} / \mathrm{ha}$ produced grain yield of $2.42 \mathrm{t} / \mathrm{ha}$ than lower levels of zinc. 1,000 grain weight and harvest index of pearlmillet was increased linearly with increasing levels of zinc but the response was not to the level of significance. Economics of pearlmillet was also influenced significantly with residual effect of zinc (Table 4). Residual effect of $5.0 \mathrm{~kg} \mathrm{Zn} / \mathrm{ha}$ fetched significantly higher profitability of ₹ 25,968 /ha with returns of $₹ 1.23$ per rupee invested. The application of zinc to chickpea crop improved the soil status of DTPA extractable zinc in the soil and increasing supply and uptake by the succeeding pearlmillet crop resulting in improvement in growth parameters and yield attributes. Thus positive impact on these characters led to significant improvement in yield of succeeding pearlmillet. Jain and Dahama (2005) and Sammauria and Yadav (2008) has also reported similar results with regards to residual effect of zinc.

In conclusion, on the basis of results of two years investigation, it could be concluded that sowing of pearlmillet either on flat bed with $5.0 \mathrm{t} / \mathrm{ha}$ crop residue or narrow bed and furrow with $2.5 \mathrm{t} / \mathrm{ha}$ crop residue and application of $2.5 \mathrm{~kg} \mathrm{Zn} / \mathrm{ha}$ were proved significantly better for the performance of pearlmillet under rainfed conditions.

\section{References}

Badiyala, D. and Chopra, P. 2011. Effect of zinc and FYM on productivity and nutrient availability in maize (Zea mays)-linseed (Linum usitatissimum) cropping sequence. Indian J. Agron., 
56(2): 88-91.

Chaube, A.K., Ruhella, R., Chakraborty, R., Gangwar, M.S., Srivastava, P.C. and Singh, S.K. 2007. Management of zinc fertilizer under pearlmillet-wheat cropping system in a Typic Ustipsamment. J. Indian Soc. Soil Sci., 55(2): 196-202.

Dass, A., Singh, A. and Rana, K.S. 2013. Insitu moisture conservation and nutrient management practices in foddersorghum (Sorghum bicolor). Ann. Agric. Res., 34(3): 254-259.

GOI. 2015. Agricultural Statistics at a glance. Directorate of Economics and Statistics, Department of Agriculture and Cooperation. Ministry of Agriculture, Government of India, New Delhi.

Gomez, K.A. and Gomez, A.A. 1984. Statistical Procedures for Agricultural Research. Second Edition, John Wiley and Sons, New York.p. 680.

Guled, M.B., Surakod, V.S. and Kabadagi, C.B. 2011. Influence of moisture conservation practices and planting geometry on rabi sorghum in vertisols. Int. J. Agric. Sci., 7(2): 444-446.

Jain, N.K. and Dahama, A.K. 2005. Residual effect of phosphorus and zinc on yield, nutrient content and uptake and economics of pearlmillet (Pennisetum glaucum)-wheat (Triticum aestivum) cropping system. Indian J. Agric. Sci., 75(5): 281-284.

Jakhar, S.R., Singh, M. and Balai, C.M. 2006. Effect of farmyard manure, phosphorus and zinc levels on growth, yield, quality and economics of pearlmillet (Pennisetum glaucum). Indian J. Agric. Sci., 76(1): 58-61.

Kumar, N. and Gautam, R.C. 2004. Effect of moisture conservation and nutrient management practices on growth and yield of pearlmillet (Pennisetum glaucum) under rainfed conditions. Indian J. Agron., 49(3): 182-185.
Maclean, J.L., Rawe, D.C. and Hettel, G.P. 2002. Rice Almanac: Source book for the most important economic activity on Earth. ( $3^{\text {rd }}$ edn.), International Rice Research Institute, Manilla, Philippines and CABI, Wallingford, UK, pp 253.

Marschner, H. 1995. Mineral nutrition of higher plants ( $2^{\text {nd }}$ edn.). London: Academic Press.

Mehta, A.C., Khafi, H.R., Bunsa, B.D., Dangaria, C.J. and Davada, B.K. 2008. Effect of soil application and foliar spray of zinc sulphate on yield, uptake and net return of pearlmillet. Res. Crops, 9(1): 31-32.

Mulumba, L.N. and Lal, R. 2008. Mulching effects on selected soil physical properties. Soil Tillage Res., 98: 106111.

Munish Kumar, Singh, R.A. and Singh, S.P. 2008. Performance of moisture conservation practices and levels of nitrogen on sorghum under rainfed ecosystem of central Uttar Pradesh. Indian J. Soil Conserv., 36(1): 22-23.

Ram Pratap, Sharma, O.P. and Yadav, G.L. 2008. Effect of integrated nutrient management under varying levels of zinc on pearlmillet yield. Ann. Arid Zone, 47(2): 197-199.

Sammauria, R. and Yadav, R.S. 2008. Effect of phosphorus and zinc application on growth and yield of fenugreek (Trigonella foenum-graecum) and their residual effect on succeeding pearlmillet (Pennisetum glaucum) under irrigated conditions of North-West Rajasthan. Indian J. Agric. Sci., 78(1): 61-64.

Sharma, A.R., Singh, R., Dhyani, S.K. and Dube, R.K. 2010. Effect of live mulching with annual legumes on performance of maize (Zea mays) and residual effect on following wheat (Triticum aestivum). Indian J. Agron., 55(3): 177-184.

Singh, R.K., Chakraborty, D., Garg, R.N., 
Sharma, P.K. and Sharma, U.C. 2010. Effect of different water regimes and nitrogen application on growth, yield, water use and nitrogen uptake by pearlmillet (Pennisetum glaucum). Indian J. Agric. Sci., 80(3): 213-216.

Singh, R.P., Yadav, P.N., Uttam, S.K., Katiyar, S.C. and Tripathi, A.K. 2012. Effect of moisture conservation and nutrient management on growth, yield and water use efficiency of sorghum (Sorghum bicolor) under rainfed conditions. Current Adv. Agric. Sci., 4(1): 37-40.

Tetarwal, J.P., Rana, K.S. and Baldev Ram.
2012. Effect of fertility levels and moisture conservation practices on production efficiency and energetics of pearlmillet intercropped mothbean. Indian J. Fert., 8(3): 36-41.

Thakur, N.S., Kushwaha, B.B. and Sinha, N.K. 2011. Productivity and water use in kharif sorghum (Sorghum bicolor) under different land configuration and mulching. Indian J. Agron., 56(1): 4751.

White, J.G. and Zasoski, R.J. 1999. Mapping soil micronutrients. Field Crop Res., 60: 11-12.

\section{How to cite this article:}

Choudhary, G.L., K.S. Rana, R.S. Bana and Prajapat, K. 2017. Impact of Moisture Management and Zinc Fertilization on Performance of Pearlmillet (Pennisetum glaucum L.) Under Rainfed Conditions. Int.J.Curr.Microbiol.App.Sci. 6(4): 1098-1107. doi: https://doi.org/10.20546/ijcmas.2017.604.137 